\title{
POTENTIAL ANALGESIC AND ANTI-INFLAMMATORY EFFECT OF CUMINUM CYMINUM AND BORAGO OFFICINALIS IN RATS AND MICE
}

\author{
GIHAN F ASAAD ${ }^{1,3 *}$, ALAA Q REDAI ${ }^{2}$, ALAA 0 HAKAMI ${ }^{2}$, FATIMAH Y GHAZWANI ${ }^{2}$, YOUSRA NOMIER ${ }^{3}$, \\ SAEED ALSHAHRANI ${ }^{3}$
}

${ }^{1}$ Department of Pharmacology, National Research Centre, Giza, Egypt. ${ }^{2}$ PharmD Candidate, College of Pharmacy, Jazan University, KSA. ${ }^{3}$ Department of Pharmacology and Toxicology, Pharmacy College, Jazan University, KSA. Email: dr_g.asaad@yahoo.com

Received: 16 October 2019, Revised and Accepted: 02 December 2019

ABSTRACT

Objective: Our research aimed to study the potential therapeutic effect of Cuminum cyminum and Borago officinalis seed oil against inflammation induced by carrageenan as well as its central and peripheral analgesic effect.

Methods: The anti-inflammatory effect was determined by measuring the edema rate and inhibition rate using Plethysmometer. Writhing test and hot plate test were used to determine the peripheral and central analgesic effect, respectively.

Key Findings: Significant anti-inflammatory effects were witnessed for all the drugs at different dose levels in the results. Substantial analgesic effect against both peripheral and central pain induction was also incurred on administration of all doses of C. cyminum and B. officinalis seed oil.

Conclusion: The C. cyminum and B. officinalis seed oil has potent anti-inflammatory and analgesic effects

Keywords: Cuminum cyminum, Borago officinalis, Inflammation, Carrageenan, Edema, Writhing, Analgesia, Tail immersion.

(C) 2020 The Authors. Published by Innovare Academic Sciences Pvt Ltd. This is an open access article under the CC BY license (http://creativecommons. org/licenses/by/4. 0/) DOI: http://dx.doi.org/10.22159/ajpcr.2020.v13i1.36107

\section{INTRODUCTION}

Inflammation is a normal protective response induced by tissue injury or infection to combat invaders in the body (microorganisms and non-self-cells) and to remove dead or damaged host cells. It has been generally accepted that the excessive production of pro-inflammatory cytokines and mediators, such as interleukin (IL)-1, IL-6, tumor necrosis factor- $\alpha$, nitric oxide, and prostaglandin (PG) $\mathrm{E}_{2}\left(\mathrm{PGE}_{2}\right)$ plays an important role in the development of inflammatory disease [1]. Nonsteroidal anti-inflammatory drugs reduce pain and inflammation by inhibiting PG production through inhibiting cyclooxygenase (COX) enzyme activity (Cox 1 and Cox 2).

Borage (Borago officinalis) is a large plant with star-shaped bright blue flowers found in most regions of the world [2]. Moreover, borage is useful in lowering levels of glucose, cholesterol, and triglycerides which can exert anti-carcinogenic effect [3]. Diet with borage oil enhances the levels of linolenic and arachidonic acid in plasma, liver, and vascular tissues. It might exert antihypertensive effect in rats [4], reduce menopause, and premenstrual syndrome [5].

Cuminum cyminum L. (family Apiaceae), is a thin aromatic herbaceous, subglabrous dicotyledonous annual plant. The major constituents in cumin seeds oil are cuminal, $\beta$-pinene, $\beta$-myrcene, $\rho$-cymene, $\gamma$-terpinene, and menthe-1,4-dien-7-ol. Cumin oil has attracted attention to their antibacterial, antifungal, antioxidant, anti-spoilage, antiplatelet, chemopreventive, and hypoglycemic activity, based on scientific results [6-9]. Nevertheless, there is no report available on the anti-inflammatory activity of cumin seeds oil [10].

The aim of current work is to evaluate the anti-inflammatory and analgesic effects of cumin seeds oil and borage seeds oil and to elucidate whether they act centrally or peripherally or both.

\section{METHODS}

Animals

150-200 g mature Wistar rats and 20-25 g mature albino mice were purchased from the animal breeding unit at the Medical Research Centre, Jazan University. This study was approved by an ethics committee of the Pharmacy College, Jazan University.

\section{Drugs and kits}

C. cyminum seed oil and Borago officinalis were purchased from SigmaAldrich. Carrageenan (a substitute for animal-based gelatins) was obtained from Sigma-Aldrich, Germany.

\section{Carrageenan induced inflammation in rats}

$0.1 \mathrm{ml}$ of $1 \%(\mathrm{w} / \mathrm{v})$ Carrageenan in distilled water was injected subcutaneously in the subplantar region of the rat's left hind paw. Rats were divided randomly into six groups, each of five animals. Group 1 is given the solvent daily without any treatment and kept as control. Group 2 will be given indomethacin $20 \mathrm{mg} / \mathrm{kg}$ orally and used as a standard group. Groups 3 and 4 will be given the $C$. cyminum oil orally in doses of 25 and $50 \mathrm{mg} / \mathrm{kg}$, respectively. Groups 5 and 6 will be given the B. officinalis oil orally in doses of 25 and $50 \mathrm{mg} / \mathrm{kg}$, respectively. All drugs were given $30 \mathrm{~min}$ before the Carrageenan injection [11]. After 1, 2, and $3 \mathrm{~h}$ of injection of $1 \%$ Carrageenan, the paw volumes using the Plethysmometer, edema rate, and inhibition rate were measured [12].

Edema rate $(\%)=\mathrm{Vt}-\mathrm{Vo} / \mathrm{Vo}$

Inhibition rate $(\%)=\mathrm{Ec}-\mathrm{Et} / \mathrm{Ec}$

Where:

Vo is the volume before Carrageenan injection ( $\mathrm{ml})$ $\mathrm{Vt}$ is the volume at $\mathrm{t}$ hour after Carrageenan injection (ml) Ec is the edema rate of control group Et is the edema rate of treated group. 
Central analgesic activity in mice (tail immersion test)

Rats were divided randomly into six groups, each of five animals. Groups 2 and 3 were given the C. cyminum oil orally in doses of 25 and $50 \mathrm{mg} / \mathrm{kg}$, respectively. Groups 4 and 5 were given the $B$. officinalis oil orally in doses of 25 and $50 \mathrm{mg} / \mathrm{kg}$, respectively. Group 6 was given acetylsalicylic acid $150 \mathrm{mg} / \mathrm{kg}$ orally and used as a control positive group. Pain was induced using a thermal stimulus by exposing the end of the mice tail to warm water maintained at $55^{\circ} \mathrm{C}$. The reaction time was calculated for each rat within $0.5 \mathrm{~s}$ unit using stopwatch, which is the interval between placing the tail in warm water and the removal of the tail from the water. The cutoff time is $20 \mathrm{~s}$. The reaction time was determined periodically before and after the oral administration of the drugs [13]

\section{Peripheral analgesic activity in mice (writhing test)}

Mice were divided randomly into six groups each of 5 animals. Group 1 is kept as control negative. Groups 2 and 3 were given the $C$. cyminum oil orally in doses of 25 and $50 \mathrm{mg} / \mathrm{kg}$, respectively. Groups 4 and 5 were given the B. officinalis oil orally in doses of 25 and $50 \mathrm{mg} / \mathrm{kg}$, respectively. Group 6 was given acetylsalicylic acid $150 \mathrm{mg} / \mathrm{kg}$ orally to be used as a control positive group. Thirty minutes before treatment with the oil of C. cyminum and B. officinalis, all the animals were injected intraperitoneally with acetic acid $(0.7 \%$ aqueous solution) at a dose of $10 \mathrm{ml} / \mathrm{kg}$ body weight. Pain is indicated with abdominal writhes. The number of writhes was calculated for a period of $20 \mathrm{~min}$ after injection [14].

Inhibition $\%=($ Control mean-Treated mean $) /$ Control mean $\times 100$

\section{Statistical analysis}

Results were compared to untreated and standard groups and analyzed using one-way analysis of variance (ANOVA) followed by Dunnett's multiple comparisons using SPSS statistics 17.0 (Chicago, USA) and expressed as means \pm standard error.

\section{RESULTS}

The potential anti-inflammatory effect of borage seed oil and cumin seed oil against Carrageenan induced inflammation was tested in 30 Wistar rats weighing 150-200 g. Rats were divided randomly into six groups each of five animals. Groups (3, 4, 5, and 6) were given two different doses (25 and $50 \mathrm{mg} / \mathrm{kg}$ ) of borage seed oil and cumin seed oil. Group 1 was not treated and kept as control and Group 2 was given indomethacin $20 \mathrm{mg} / \mathrm{kg}$ orally and used as a reference group. All the animals were injected with
Carrageenan 1\% in the left hind paw. Edema rates were monitored throughout the experiment at an interval of 1, 2, and $3 \mathrm{~h}$ after Carrageenan injection, and results were analyzed and compared with both control and reference groups. Table 1 showed a sustained increase in edema rate for the whole experiment interval in the control group (120.65\%, 76.9, and 72.83) compared with the reference group given indomethacin which showed an increase in inhibition rate (49.5\%, 19.01\%, and $4.68 \%)$ after $1^{\text {st }}, 2^{\text {nd }}$, and $3^{\text {rd }} \mathrm{h}$, respectively. Administration of both oils in all doses showed a significant decrease in edema rate compared to the control group after 1,2 , and $3 \mathrm{~h}$ of carrageenan injection. The anti-inflammatory potency of both borage and cumin seed oil was calculated by comparing their inhibition with that of the indomethacin. It was found that the antiinflammatory potency for all doses decreased by the end of the experiment interval compared to Indomethacin. It was evident that the group given cumin seed oil at a dose of $50 \mathrm{mg} / \mathrm{kg}$ body weight, showed the highest antiinflammatory potency and inhibition rate among all the drugs along with the reference drug after $2 \mathrm{~h}$ from the administration of the drugs.

The tail immersion test is used to elucidate the central analgesic effect which focuses mainly on changes that occur at the spinal level. Our results shown in Table 2 determined that all drugs along with standard at significance $\mathrm{p}<0.05$ reduced the pain as compared to the control group. Applying one-way ANOVA followed by Dunnett's multiple comparisons $\mathrm{p}<0.05$, it was found that there was a significant analgesic effect at $180 \mathrm{~min}$ of borage oil at a dose of $50 \mathrm{mg} / \mathrm{kg}$ body weight compared to the standard group.

In Table 3 all the drugs showed significant analgesic effect determined by reducing the number of abdominal constrictions and stretching of the hind limbs compared with the control group, which were given only acetic acid. By applying Dunnett's test, it was apparent that borage seed oil at both doses and cumin seed oil at high doses showed significant analgesic effect compared to the standard drug (acetylsalicylic acid $150 \mathrm{mg} / \mathrm{kg}$ body weight). The standard drug exhibited writhing inhibition percent (53.74\%), borage seed oil ( $25 \mathrm{mg} / \mathrm{kg}$ body weight) (68.25\%), borage seed oil (50 mg/kg body weight) (84.89\%), cumin seed oil (25 mg/kg body weight) $(60.58 \%)$ and cumin seed oil ( $50 \mathrm{mg} / \mathrm{kg}$ body weight) $(70.64 \%)$.

\section{DISCUSSION}

The current study outlines the potential anti-inflammatory and analgesic effects of $C$. cyminum and $B$. officinalis seed oil. The anti-inflammatory

Table 1: Anti-inflammatory activity of borage seed oil and cumin seed oil (Carrageenan test)

\begin{tabular}{|c|c|c|c|c|c|c|}
\hline \multirow[t]{2}{*}{ Animal groups } & \multicolumn{2}{|l|}{$1 \mathrm{~h}$} & \multicolumn{2}{|l|}{$2 \mathrm{~h}$} & \multicolumn{2}{|l|}{$3 \mathbf{h}$} \\
\hline & Edema \% & Inhibition $\%$ & Edema\% & Inhibition \% & Edema\% & Inhibition $\%$ \\
\hline Group I (Control -ve) & 120.65 & - & 76.9 & - & 72.83 & - \\
\hline Group VI (Indomethacin $20 \mathrm{mg} / \mathrm{kg}$ bwt) & $49.59^{a}$ & $58.9^{\mathrm{a}}$ & $19.01^{\mathrm{a}}$ & $75.28^{\mathrm{a}}$ & $4.68^{\mathrm{a}}$ & $93.57^{\mathrm{a}}$ \\
\hline Group II (Borage oil 25 mg/kg bwt) & $92.93^{\mathrm{a}}$ & $22.97^{\mathrm{a}}$ & $52.99^{\mathrm{a}}$ & $31.1^{\mathrm{a}}$ & $48.91^{\mathrm{a}}$ & $32.84^{\mathrm{a}}$ \\
\hline Group III (Borage oil 50 mg/kg bwt) & 107.47 & $10.92^{\mathrm{a}}$ & $63.22^{\mathrm{a}}$ & $17.79^{\mathrm{a}}$ & $54.89^{\mathrm{a}}$ & $24.64^{\mathrm{a}}$ \\
\hline Group IV (Cumin oil 25 mg/kg bwt) & $91.67^{\mathrm{a}}$ & $24.02^{\mathrm{a}}$ & $36.62^{\mathrm{a}}$ & $56.28^{\mathrm{a}}$ & $53.45^{\mathrm{a}}$ & $26.61^{\mathrm{a}}$ \\
\hline Group V (Cumin oil 50 mg/kg bwt) & $98.3^{\mathrm{a}}$ & $18.53^{\mathrm{a}}$ & $14.49^{\mathrm{ab}}$ & $81.16^{\mathrm{ab}}$ & $29.98^{\mathrm{a}}$ & $60.21^{\mathrm{a}}$ \\
\hline
\end{tabular}

Values represent the mean (Edema\% and Inhibition\%) of five rats for each group. Each value in parenthesis indicates the percentage inhibition rate.

${ }^{a} \mathrm{p}<0.05$ : Statistically significant from control (LSD followed by Dunnett's test). ${ }^{\mathrm{b}} \mathrm{p}<0.05$ : Statistically significant from indomethacin (LSD followed by Dunnett's test). The potency was calculated compared to the reference drug indomethacin. LSD: Least significant difference, bwt: body weight

Table 2: Central analgesic activity of borage seed oil and cumin seed oil (Tail immersion test)

\begin{tabular}{|c|c|c|c|c|c|}
\hline Reaction time & 0 time & $60 \mathrm{~min}$ & $90 \mathrm{~min}$ & $120 \mathrm{~min}$ & $180 \mathrm{~min}$ \\
\hline Group I (Control -ve) & $3.42 \pm 0.33$ & $3.7 \pm 0.35$ & $3.9 \pm 0.4$ & $4.5 \pm 0.37$ & $4.8 \pm 0.5$ \\
\hline Group II (Borage oil 25 mg/kg bwt) & $3.56 \pm 0.34$ & $6.13 \pm 0.75^{\mathrm{a}}$ & $7.13 \pm 0.65^{\mathrm{a}}$ & $12.28 \pm 1.5^{\mathrm{a}}$ & $15.4 \pm 1.7^{\mathrm{a}}$ \\
\hline Group III (Borage oil 50 mg/kg bwt) & $3.25 \pm 0.25$ & $4.03 \pm 0.5$ & $6.15 \pm 0.72^{\mathrm{a}}$ & $12.5 \pm 0.85^{\mathrm{a}}$ & $18.5 \pm 1.9^{b}$ \\
\hline Group IV (Cumin oil 25 mg/kg bwt) & $3.4 \pm 0.3$ & $8.36+0.67^{a}$ & $9.5 \pm 0.9^{\mathrm{a}}$ & $10.5 \pm 0.9^{a}$ & $13.2 \pm 2.02^{\mathrm{a}}$ \\
\hline Group V (Cumin oil 50 mg/kg bwt) & $3.2 \pm 0.5$ & $8.56 \pm 0.92^{\mathrm{a}}$ & $10.5 \pm 1.02^{\mathrm{a}}$ & $11.5 \pm 1.5^{\mathrm{a}}$ & $15 \pm 1.23^{\mathrm{a}}$ \\
\hline Group VI (Acetylsalicylic acid $150 \mathrm{mg} / \mathrm{kg}$ bwt) & $3.0 \pm 0.45$ & $9.3 \pm 0.85^{\mathrm{a}}$ & $12.1 \pm 1.5^{\mathrm{a}}$ & $14.1 \pm 1.4^{\mathrm{a}}$ & $14.1 \pm 1.5^{\mathrm{a}}$ \\
\hline
\end{tabular}

Values represent the mean \pm SE of five mice for each group. ${ }^{\mathrm{a} p}<0.05$ : Statistically significant from control (LSD followed by Dunnett's test). ${ }^{\mathrm{b}} \mathrm{p}<0.05$ : Statistically significant from acetylsalicylic acid (LSD followed by Dunnett's test). LSD: Least significant difference, bwt: body weight, SE: Standard error 
Table 3: Peripheral analgesic activity of borage seed oil and cumin seed oil (Writhing test)

\begin{tabular}{lll}
\hline Animal groups & $\begin{array}{l}\text { Number of } \\
\text { writhes in 30 min }\end{array}$ & $\begin{array}{l}\text { Inhibition } \\
\text { \% }\end{array}$ \\
\hline Group I (Control -ve) & $48.5 \pm 5.2$ & 0 \\
Group II (Borage oil 25 mg/kg bwt) & $15.4 \pm 0.45^{\text {ab }}$ & 68.25 \\
Group III & $7.33 \pm 0.63^{\text {ab }}$ & 84.89 \\
(Borage oil 50 mg/kg bwt) & & \\
Group IV (Cumin oil 25 mg/kg bwt) & $19.12 \pm 0.9^{\text {a }}$ & 60.58 \\
Group V (Cumin oil 50 mg/kg bwt) & $14.24 \pm 1.2^{\text {ab }}$ & 70.64 \\
Group VI (Acetylsalicylic acid & $22.44 \pm 1.5^{\text {a }}$ & 53.74 \\
150 mg/kg bwt) & & \\
\hline
\end{tabular}

Values represent the mean \pm SE of five mice for each group. ${ }^{a} \mathrm{p}<0.05$ : Statistically significant from control (LSD followed by Dunnett's test). ${ }^{\mathrm{b}} \mathrm{p}<0.05$ : Statistically significant from acetylsalicylic acid (LSD followed by Dunnett's test).

LSD: Least significant difference, bwt: body weight, SE: Standard error

effect was evaluated by carrageenan-induced paw inflammation which is a standard assay for acute inflammation. Serotonin histamine is released up to $1 \mathrm{~h}$ at the first phase of inflammation where the PG [15], bradykinin and lysosomes are releases during the second phase for another $1 \mathrm{~h} \mathrm{[16]}$. The anti-inflammatory potency of both borage and cumin seed oil was calculated by comparing their inhibition with that of the indomethacin, it was found that the anti-inflammatory potency for all doses decreased by the end of the experiment interval compared to indomethacin. It was worthy to note that group given cumin seed oil at a dose of $50 \mathrm{mg} / \mathrm{kg}$ body weight, showed the highest antiinflammatory potency and inhibition rate among all the drugs along with the reference drug after $2 \mathrm{~h}$ from the administration of the drugs. Our results suggested that $C$. cyminum and $B$. officinalis seed oil may contribute to PG synthesis inhibition.

The analgesic effect of $C$. cyminum and B. officinalis seed oil was tested in mice using two assays, tail immersion test which is used to determine central analgesic effect and writhing test which is used to determine the peripheral analgesic effect in mice. Pain is centrally modulated by many processes such as opiate, dopaminergic descending noradrenergic, and serotonergic system [17-19]. The significant decrease in pain sensation to heat stimuli through immersion of the end of mice tail in hot water maintained at $55^{\circ} \mathrm{C}$ was observed with all tested drugs along with the standard drug suggested the involvement of central pain pathways.

The evaluation of the peripheral analgesic effect is tested by the abdominal constriction response induced by acetic acid injection intraperitoneally in mice. The acetic acid induce pain by releasing serotonin, histamine, PGs, bradykinins, and substance P. The local peritoneal receptors are involved in the abdominal constriction response [20]. This method also showed an increase in $\mathrm{PGE}_{2}$ and PGF2 $\alpha$ and lipoxygenase products [21].

Our study showed that the analgesic effect produced by $C$. cyminum and B. officinalis seed oil may be through central mechanism involving opiate, dopaminergic descending noradrenergic, and serotonergic systems, or through peripheral mechanism involving inhibition the synthesis of PGs, bradykinins, and substance P.

Finally, we concluded that the C. cyminum and B. officinalis seed oil has potent anti-inflammatory and analgesic effects. Being natural components; they will also help in reducing the side effects of nonsteroidal anti-inflammatory drugs. From observations and our outlines that have led our interest in future studies toward the effects of C. cyminum and B. officinalis on different ILs which are the mediators of inflammatory and pain responses.

\section{ACKNOWLEDGMENT}

The authors are thankful to the authorities of Jazan University, Saudi Arabia (Future Scientist 6) for providing funds and necessary facilities to carry out this research work.

\section{AUTHORS' CONTRIBUTIONS}

Experimentation and manuscript preparation were done by the authors: Gihan F Asaad. Formulation of the experimental design and the manuscript was edited by Gihan F Asaad, Yousra Nomier, and Saeed Alshahrani. Practical work and animal models were conducted by authors: Gihan F Asaad, Yousra Nomier, Alaa Q Redai, Alaa O Hakami, and Fatimah Y Ghazwani.

\section{CONFLICTS OF INTEREST}

The authors declared that there are no conflicts of interest.

\section{REFERENCES}

1. Adebisi MI, Abubakar A, Abubakar K, Giaze RT. Analgesic effect and anti-inflammatory activity of aqueous extract of Boswellia dalzielii (Burseraceae) stem bark. Int J Pharm Pharm Sci 2018;10:139-42.

2. Grieve M. A Modern Herbal. New York: Dover Publications; 1971. p. 119.

3. Foolad N, Brezinski EA, Chase EP, Armstrong AW. Effect of nutrient supplementation on atopic dermatitis in children: A systemic review of probiotics, prebiotics, formula, and fatty acids. JAMA Dermatol 2013;149:350-5.

4. Mankowska G, Bylka G. Genetic resources of Cannabis sativa L. At the institute of natural fibers and medicinal plants in Poznan. Herb Pol 2009;55:178-84

5. Engler M, Engler M. Dietary borage oil alters plasma hepatic and vascular tissue fatty acids composition in spontaneously hypertensive rats. Prostaglandins Leukot Essent Fatty Acids 1998;59:11-15.

6. Lee HS. Cuminaldehyde: Aldose reductase and $\alpha$-glucosidase inhibitor derived from Cuminum cyminum L. seeds. J Agric Food Chem 2005;53:2446-50.

7. Platel K, Srinivasan K. Influence of dietary spices and their active principles on pancreatic digestive enzymes in albino rats. Nahrung 2000;44:42-6

8. Topal U, Sasaki M, Goto M, Otles S. Chemical compositions and antioxidant properties of essential oils from nine species of Turkish plants obtained by supercritical carbon dioxide extraction and steam distillation. Int J Food Sci Nutr 2008;59:619-34.

9. Wanner J, Bail S, Jirovetz L, Buchbauer G, Schmidt E, Gochev V, et al. Chemical composition and antimicrobial activity of cumin oil (Cuminum cyminum, Apiaceae). Nat Prod Commun 2010;5:1355-8

10. Juan W, Xitong Z, Bi Y, Miao R, Zhang Z, Su H. Anti-inflammatory effects of cumin essential oil by blocking JNK, ERK, and NF- $\kappa \mathrm{B}$ signaling pathways in LPS-stimulated RAW 264.7 cells. Evid Based Complement Alternat Med 2015;2015:474-509.

11. Winter CA, Risley EA, Nuss GW. Carrageenin-induced edema in hind paw of the rat as an assay for antiiflammatory drugs. Proc Soc Exp Biol Med 1962;111:544-7.

12. Khalifa NM, Al-Omar MA, Amr Ael-G, Baiuomy AR, AbdelRahman RF. SYNTHESIS and biological evaluation of some novel fused thiazolo[3,2a]pyrimidines as potential analgesic and antiinflammatory agents. Bioorg Khim 2015;41:218-26.

13. Turner RA. Screening Methods in Pharmacology. New York: Academic Press; 1965. p. 158.

14. Olaleye SB, Farombi EO, Adewoye EA, Owoyele BV, Onasanwo SA, Elegbe RA. Analgesic and anti-inflammatory effects of kolaviron (a Garcinia kola seed extract). Afr J Biomed Res 2000;3:171.

15. Subhashis P, Somit D, Tapas KC, Soumen B. Anti-inflammatory and protective properties of aloe vera leaf crude gel in carrageenan induced acute inflammatory rat models. Int J Pharm Pharm Sci 2014;6:368-71.

16. Crunkhorn P, Meacock SC. Mediators of the inflammation induced in the rat paw by carrageenan. Br J Pharmacol 1971;42:392-402.

17. Bensreti MM, Sewell RD. Selective effects of dopaminergic modifiers on antinociception produced by different opioid receptor agonists. Pro Br Pharmacol Soc 1983;28:70.

18. Headley PM, Shaughnessy CT. Evidence for opiate and dopamine interaction in striatum. Br J Pharmacol 1985;86:700.

19. Wigdor S, Wilcox GL. Central and systemic morphine-induced antinociception in mice: Contribution descending serotonergic and noradrenergic pathways. J Pharmacol Exp Ther 1987;242:90.

20. Bentley GA, Newton SH, Starr J. Studies on the antinociceptive action of agonist drugs and their interaction with opioid mechanisms. $\mathrm{Br} \mathrm{J}$ Pharmacol 1983;79:125.

21. Derardt R, Jongney S, Delevalcee F. Release of prostaglandins E and F in an algogenic reaction and its inhibition. Eur J Pharmacol 1980;51:17. 